\title{
Histopathological Aspects Described in Patients with Hepatic Hydatidosis
}

\author{
DANIELA E. MIHĂILĂ $\breve{1}^{1}$, M.C. NIȚU², T.D. POTECĂ $\breve{~}^{1}$ \\ ${ }^{1}$ Surgical Unit, "Colentina" Clinical Hospital, Bucharest, Romania \\ ${ }^{2}$ Pathology Department, "Colentina” Clinical Hospital, Bucharest, Romania
}

\begin{abstract}
Introduction. Hydatidosis is a parasitic disease with tumour-like development of a cystic mass. This has specific endemic areas, Romania being amongst them. Our hospital has national addressability and the collaboration between the Departments of Parasitology, General Surgery and Pathology ensures optimal multidisciplinary approach to cases of therapeutic and diagnostic standpoint. The study aims to test the hypothesis that the gallbladder is a hydatid reservoir, to identify signs of biliary fistulas in the pericyst and liver parenchyma; to identify inflammation elements in the pericyst and the gallbladder.

Material and methods. The study is a retrospective observational one, carried out between 2011-2014, on a total of 35 patients operated for hepatic hydatidosis in the General Surgery Department of "Colentina" Clinical Hospital. All the selected patients had sent to the Pathology Department: gallbladder, cyst and pericyst. Statistical analysis of the data was performed using SPSS package Statistics 19.

Results. The main results of the study revealed no evidence to confirm the hypothesis that the gallbladder is a hydatid reservoir. Out of the 35 cases, in 16 we observed the tendency to include hepatic biliary ducts in the pericyst or the formation of new canals which lead to the formation of biliary fistulas. Using immunohistochemical techniques with mark of CK19 (cytokeratin 19), have been observed the pattern of fistulization and modification of local architecture through the formation of the pericyst, in 16/35 (45.7\%) of cases.

Conclusion. Although it is a benign pathology, the evolution of hepatic hydatidosis can lead to severe complications and a low quality of life for the patient, both before and after surgery. Better knowledge of the pathology behind the local evolution of the disease can influence the therapeutic approach.
\end{abstract}

Key words: hydatid cyst, biliary fistula, fibrosis, immunohistochemistry, CK19 in hydatidosis.

\section{INTRODUCTION}

Hydatidosis is a benign pathology which can lead to several complications that can even cost the life of the patient. It is a common parasitosis due to a tape worm Echinooccus granulosus, with a tumour-like cystic evolution, mostly in the liver or the lung. Humans get infected by the larval stage of the parasite, whose adults live in carnivorous animals [1]. The embryo passes through the intestinal wall and reaches the port system vessels, in the majority of cases it stops in the hepatic filter. Once implanted in the port capillary, the parasite develops in the parenchyma a liquid formation, the hydatid vesicle that continues growing until it modifies the liver architecture. Inside the cystic tumour there is a clear fluid and multiple protoscolices, each of them a future adult taenia. Due to the specific vessel network, the right liver is most frequently affected by the disease [2]. The development of the cyst needs the succession of 4 phases: the cuticle development, growth, germination and secretion of hydatid liquid [3]. The cyst has two layers (of parasitic nature), not merging with each other, but in close contact: the cuticle and the germinative membrane. The cyst fluid is clear, with neutral $\mathrm{pH}$, containing proteins, ions, lipids and content of ruptured vesicles (protoscolices, debris of membrane, hooklets) [4]. With growth and time the outer layer of the cyst starts to create local fibrosis and inflammatory response, which leads to a great number of eosinophils in the wall [5]. According to some authors, hydatidosis is still a frequent parasitic disease that causes a considerable mortality. The main causes of mortality in patients with hydatidosis are complications related to the rupture of the cysts with supurative collangitis [6]. 
This study aimed to test the theory of a hydatid reservoir in the gallbladder, to determine signs of biliary fistulas in the parenchyma and to analyze the cellular elements of inflammation in the pericyst or the cholecyst. Although the pathology analysis comes after the therapeutic act, it helps to raise the understanding of the local implications of the cysts existence and possible complications derived from this.

The expression of CK19 (cytokeratin 19) is associated with multiple malignant tumors [7], but also with benign liver cystic lesions and biliary tract pathology [8].

\section{MATERIAL AND METHODS}

The design of this project was a retrospective observing study. The study group consisted of 68 subject operated between 2011-2014 in the Surgery Department of "Colentina" Clinical Hospital. We have chosen 35 of them the inclusion criteria being: patients who had surgery for liver hydatidosis; the Pathology lab had 3 pieces for each patient: gallbladder, cyst, pericyst. The study included macroscopic and microscopic aspects, immunohistochemistry of the pieces. All pieces were observed by a pathologist with optical devices and using Hematoxylin and Eosin (H\&E) Staining Protocol. We also included immunohistochemical studies on the specimens, using cytokeratin 19, most used marker in hepatic and gastrointestinal lesions [9]. The study aims to test the hypothesis that the gallbladder is a hydatid reservoir, to identify signs of biliary fistulas in the pericyst and liver parenchyma; to identify inflammatory elements in the pericyst and the gallbladder. For the descriptive statistics we used Excel 2007 and SPSS Statistics 19.

\section{RESULTS}

The studied group was analysed from a demographic point of view, surgical procedures, cyst characteristics and pathology considerations regarding the inflammatory process and the presence of the fistulas.
The group consisted of 22 females (62.9\%) and 13 males $(37.1 \%)$, with a median age of 41.9 years. The average hospital stay for the selected patients was 22.9 days after the surgery, with no significant complications, other than the presence of biliary fistula in 25 cases.

The 35 patients group had a total of 53 cysts, 15 patients having at least 2 hepatic cysts and multiple liver segments involved, due to the large dimensions of the cystic mass. The mean cyst diameter was $9.4 \mathrm{~cm}$ (with largest cyst of $20 \mathrm{~cm}$ and $5 \mathrm{~cm}$ the smallest one). The distribution of the cysts in the 8 liver segments (including the multisegment ones) together with the incidence of biliary fistula is represented in Figure 1.

Considering the surgical approach, the location and dimension of the cyst dictated the technique. In this group all patients had cholecystectomy associated with: cystectomy, pericystectomy and cavitary drainage (26 cases); digestive anastomosis with Witzel drainage ( 6 cases) and ideal cystectomy in 5 cases.

The pathology descriptive analysis verified our hypothesis and concluded that regarding the gallbladder being a possible parasitic reservoir there were no data found (none of the specimens presented any parasitic element). Nonetheless, we found $18 / 35(51 \%)$ of cases presented signs of chronic sclero-atrophic cholecystitis (Figure 2) and significant pericystic fibrosis (H-E staining). Regarding the inflammatory aspect of the cholecyst, 5/35 (14.2\%) of cases showed rare eosinophils $(<2-3$ on 10 high power field - HPF) - Figure 3.

The specimens of pericyst included in the study revealed that $22 / 35(62.8 \%)$ cases had eosinophils in the inflammatory infiltrate (Figure 4), with various degrees of density in the examined fields, as shown in Table 1.

Considering the great importance of the presence of the biliary fistula in the evolution of a surgical case of liver hydatid cyst, we determined through CK19 immunohistochemical reaction the presence of native and new biliary ducts in the pericyst (Figures 5,6) - 15/35 cases.

The positive reading to CK19 marking is also found in patients that did not present any clinical fistula, as shown in Figure 7. 


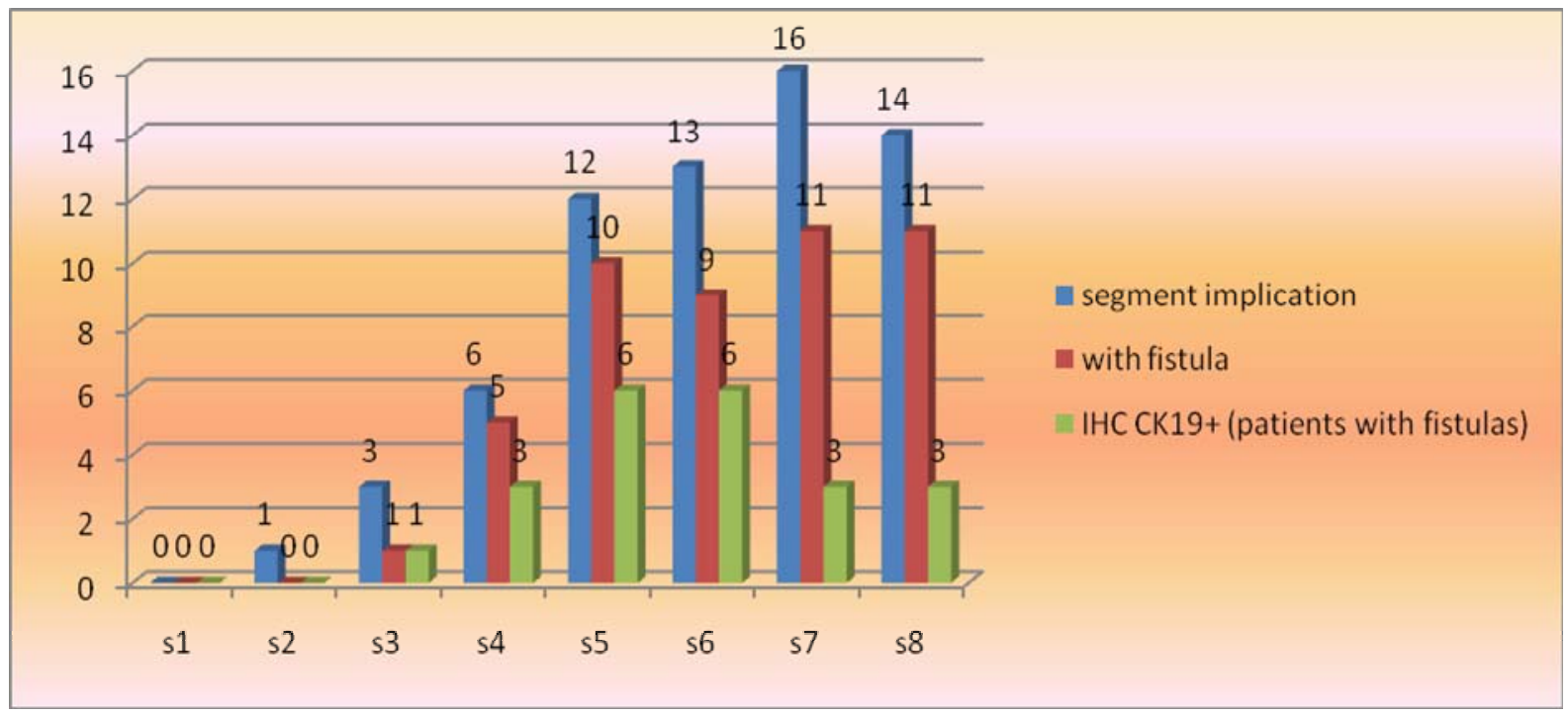

Figure 1. Segments of the right hepatic lobe were most affected by the parasite (VII, VIII) and also presented most cases of biliary fistula, although the CK19 immunohistochemical reaction was more frequent in the marginal segments of the right lobe (V, VI).

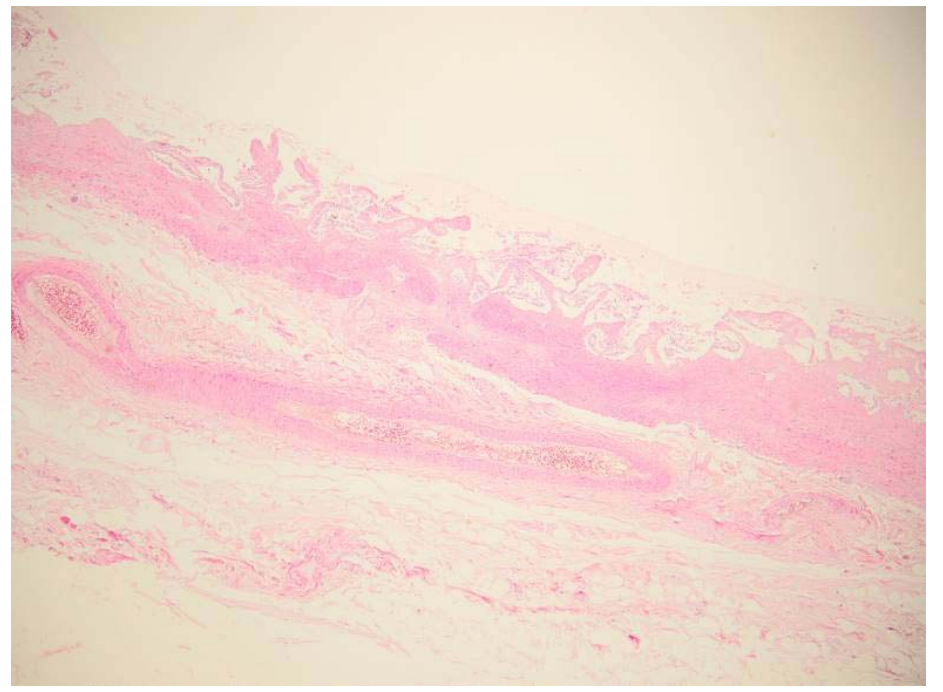

Figure 2. Chronic sclero-atrophic cholecystitis; Hematoxylin and Eosin (H\&E) Staining.

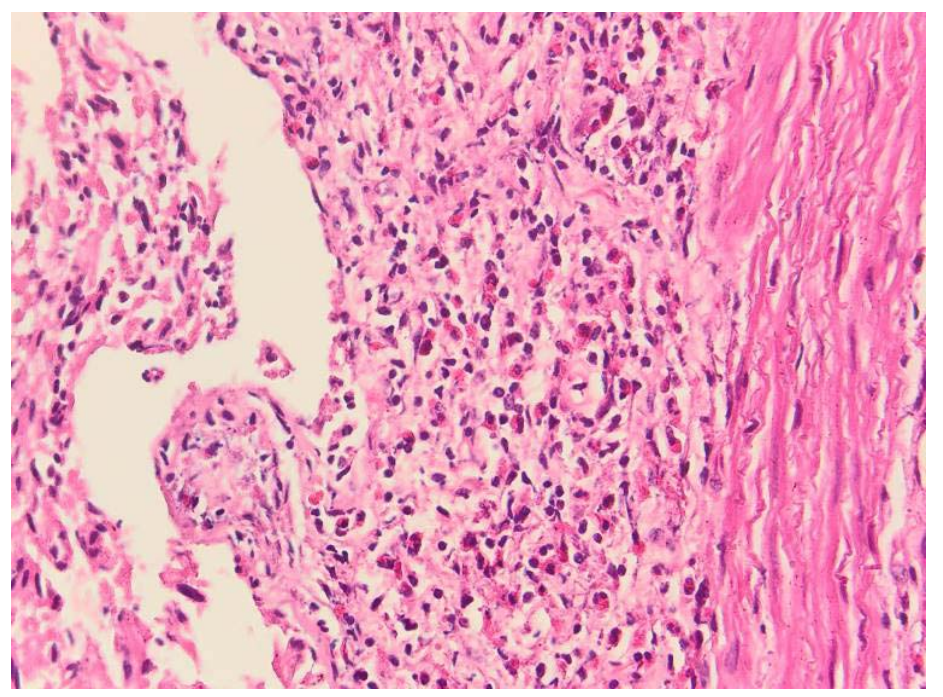

Figure 3. Inflammatory infiltrate rich in eosinophils in the corion of a gallbladder (detail); H\&E Staining. 


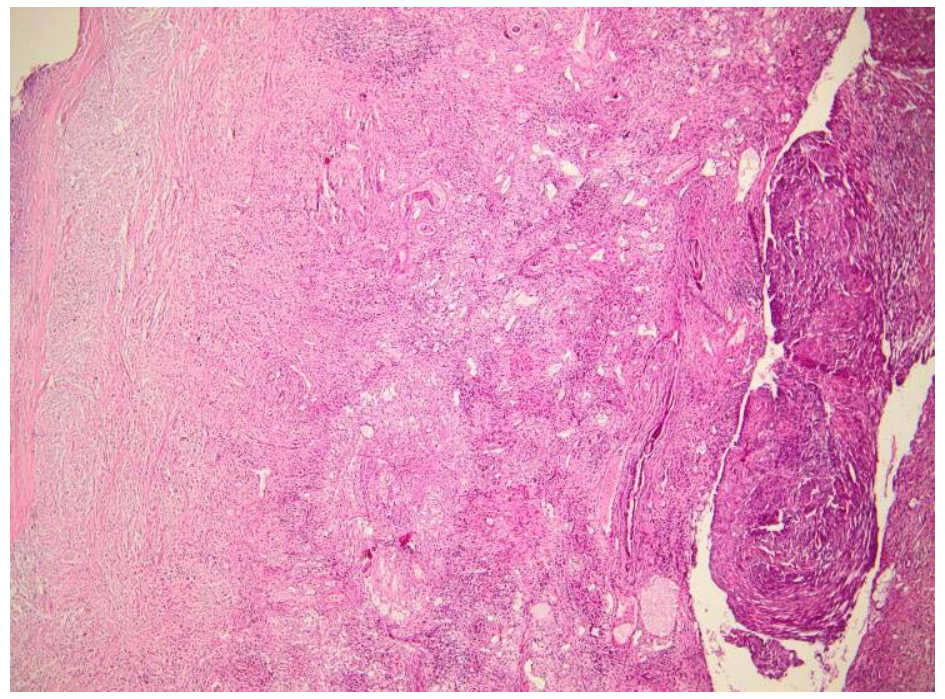

Figure 4. General view in H\&E of pericyst with rich eosinophils inflammatory infiltrate.
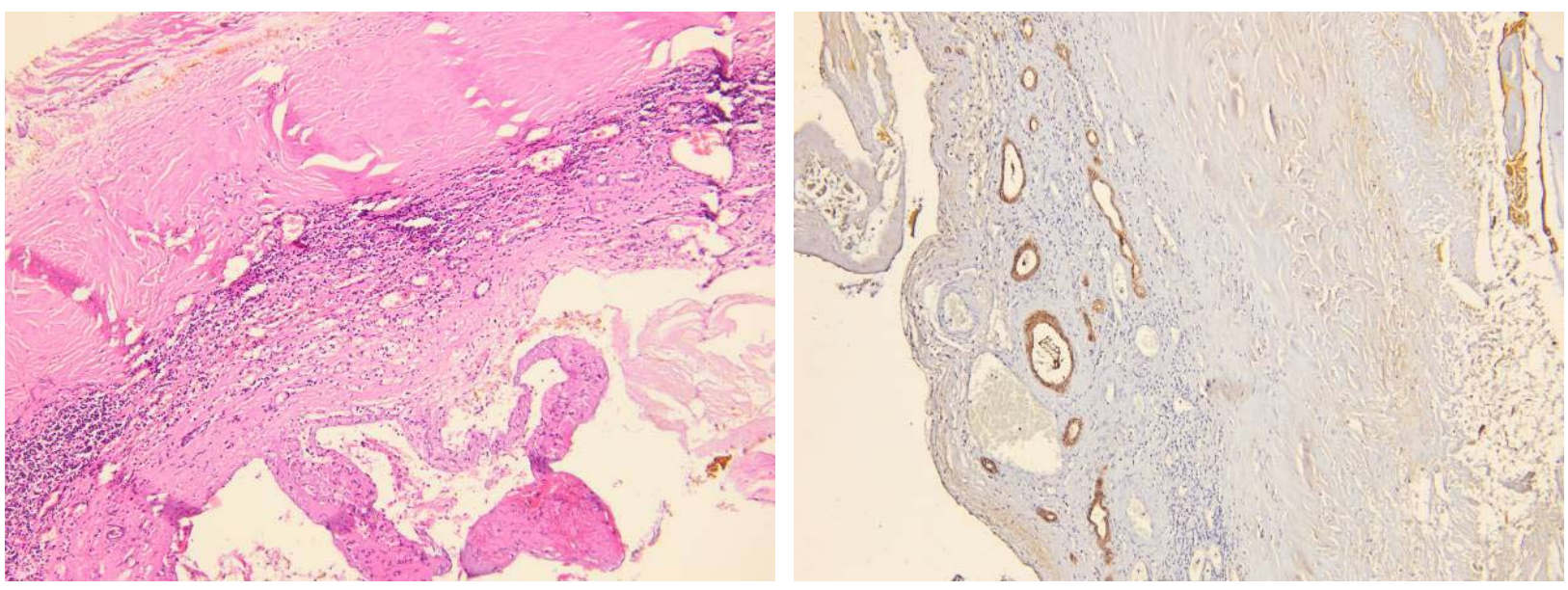

Figures 5 and 6. Pericyst: H\&E stained Perichist (left) and CK19 marked in the same section (right) emphasizing the bile ducts.

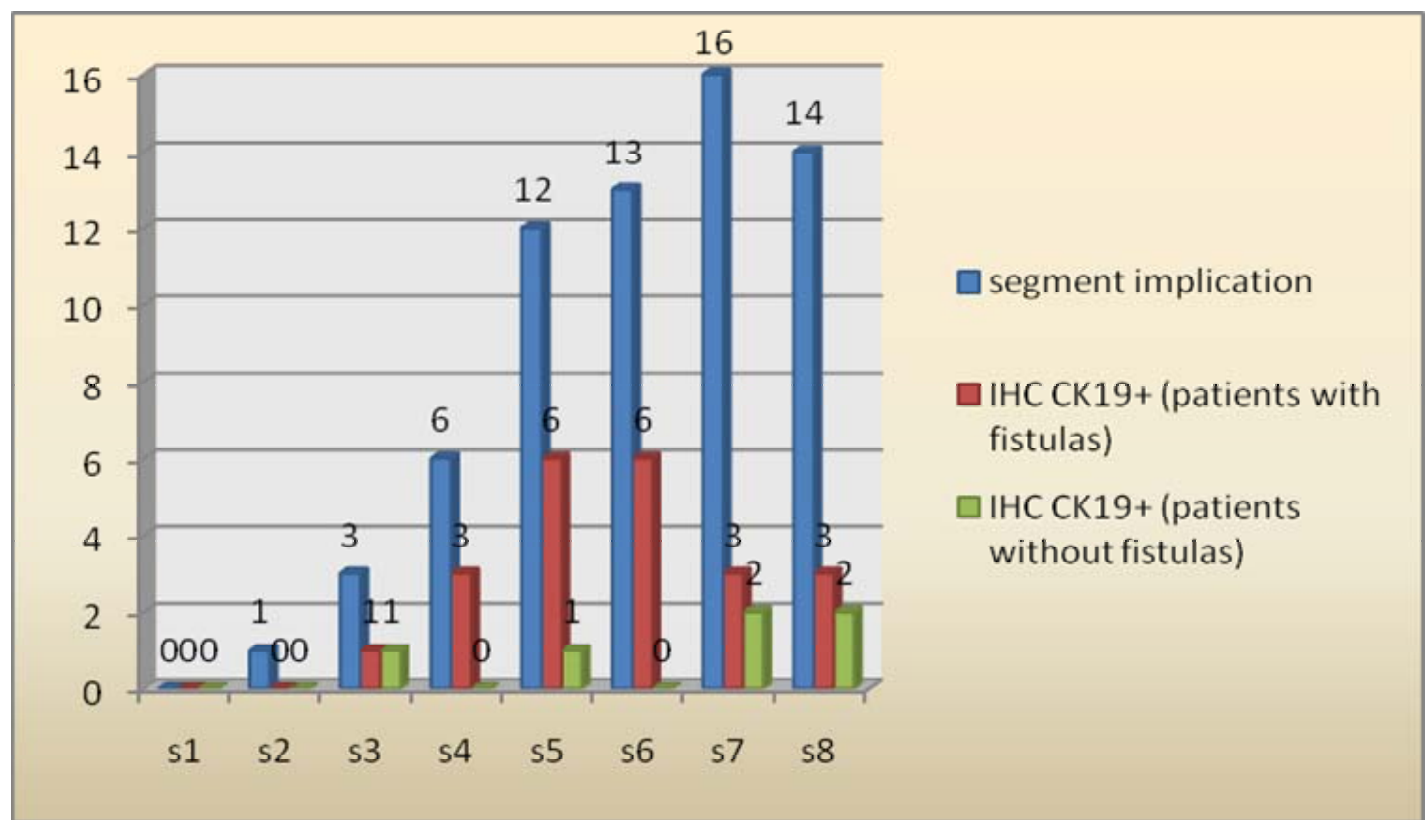

Figure 7. Patients with biliary ducts observed through immunohistochemical detection, in both groups (with and without fistula). 
Table 1

Eosinophils in the pericysts inflammatory infiltrate

\begin{tabular}{|l|c|c|c|}
\hline \multicolumn{1}{|c|}{ Density } & Number/HPF & No. of cases & Percent \\
\hline High & $>10$ & 8 & 22.8 \\
\hline Moderate & $3-10$ & 5 & 14.2 \\
\hline Low & $<2-3$ & 9 & 25.8 \\
\hline
\end{tabular}

\section{DISCUSSION}

A primary hydatid cyst of the liver is composed of 3 layers (adventitia - compressed liver parenchyma, ectocyst - elastic membrane and endocyst - germinal epithelium) [10]. The 3 layers of the liver hydatid cyst are in close relation of development. The outer pericyst is the reaction of the host to the parasite presence; it is composed of modified host cells and fibrosis. We can observe the presence of vessels and biliary ducts in the pericyst, as the primary architecture of the affected organ is preserved. The middle membrane is a laminated layer, acellular, very elastic, allows the growth of the cyst and its nutrition; nutrients (colloids and crystalloids) have osmotic passage through this gelatinous structure, about $1 \mathrm{~mm}$ thick. This structure starts to decay when the parasite is in distress [2].

The germ membrane has less resistance to trauma, presents itself with a great number of nuclei and has a double role: helps the parasite reproduce and secretes the cyst's liquid. This layer permits also the development of "daughter vesicles".

The hydatid sand found in the clear liquid has the immunological capacity of response, and both can generate the anaphylactic reaction of the host [11]. Also, the hydatid liquid is known to contain $\mathrm{Na}, \mathrm{K}, \mathrm{Mg}, \mathrm{Cu}, \mathrm{Fe}$ and $\mathrm{P}$ ions, lipids, proteins and aminoacids [12].

Although there was no proof that the presence of the parasite can influence the development of the chronic cholecystitis, the two pathologies frequently associated and thus the surgical cure of the cyst often included cholecystectomy.

The presence of biliary ducts in the pericyst proves that the tumour like cystic formation acts in parallel to the inflammatory and fibrous response of the liver, keeping its normal architecture. The opened ducts in the outer layer of the cyst create the opportunity for biliary fistula.

The presence of the immunological elements of the cyst contributes to the recurrence rate of the disease.
The average growth rate of the cyst is of 1-15 $\mathrm{mm} /$ year or, in a rapid form, of $>30 \mathrm{~mm} /$ year [13]; the average dimension of $9 \mathrm{~cm}$ in our group indicates old cysts, thus the inflammatory local reaction in the pericyst, with the integration of the biliary ducts is to be expected. Also, the chronic local evolution of the cyst explains the large number of chronic cholecystitis and the impregnation of eosinophils of the infiltrate in the gallbladder and in the pericyst.

Although there were some eosinophils in the cholecystic inflammatory infiltrate, their number was not sufficient to talk about "eosinophilic cholecystitis", which remains a rare entity [14].

In hydatidosis the morphological diagnosis by the pathologist is frequently made by the presence of hydatid elements, especially hooklets, viewed in H\&E coloration or Ziehl-Neelsen stain (not used in our study) [15].

\section{CONCLUSIONS}

The analysis of the study group tested and proved the hypothesis: gallbladder does not seem to be a parasite reservoir; eosinophils seem to infiltrate tissue around the cyst about two thirds of cases, but not neighbouring organs (cholecystitis); the tendency to fistula is supported by the cysts age and CK19 marked specimens.

The correlation between the cysts location, dimension and surgical procedure, with possible complications, is known [2] and also proven by our study. Other studies [16, 17] from endemic areas reported similar conclusions regarding the demographic aspects, cyst characteristics, study lot data and the pathology description. The study of pathological aspects of hydatidosis is an old interest topic that once opened can help prevent recurrence or better understanding of the complications likely to produce.

\footnotetext{
Acknowledgement. This paper is supported by the Sectoral Operational Programme Human Resources Development (SOP HRD), financed from the European Social Fund and by the Romanian Government under the contract number POSDRU/ 159/1.5/S/137390"
} 
Introducere. Hidatidoza este o parazitoză cu dezvoltare pseudotumorală a unei mase chistice. Boala are caracter endemic, inclusiv în România. Spitalul nostru are adresabilitate națională, colaborarea dintre departamentele de parazitologie, chirurgie şi anatomie patologică asigurând o abordare optimă multidisciplinară a cazurilor din punct de vedere terapeutic şi diagnostic. Studiul îşi propune testarea ipotezei conform căreia colecistul este un rezervor hidatic; identificarea semnelor de existență a fistulelor biliare la nivelul perichistului şi parenchimului hepatic, precum şi a identificării elementelor de inflamație de la nivelul perichistului sau colecistului.

Material şi metode. Studiul de față este retrospectiv-observațional, realizat în perioada 2011-2014, pe un număr de 35 de pacienți operați pentru hidatidoză hepatică în Departamentul de Chirurgie Generală a Spitalului Clinic Colentina. De la toți pacienții s-au trimis la Departamentul de Anatomie Patologică: colecist, chist şi perichist. Analiza statistică a datelor a fost realizată utilizând pachetul SPSS Statistics 19.

Rezultate. Principalele rezultate ale studiului nu au evidențiat elemente care să confirme ipoteza conform căreia colecistul este un rezervor hidatic. Din cele 35 de cazuri, in 16 cazuri s-a constatat tendința de incluziune a ductelor biliare hepatice in perichist sau formarea de ducte noi, fapt care a condus la constituirea de fistule biliare. Folosind tehnici de imunohistochimie, cu marcare cu CK19 (citokeratina 19), s-a observat tendința de fistulizare şi modificare a arhitecturii locale, prin formarea perichistului, în 16/35 (45,7\%) din cazuri.

Concluzii. Deşi este o patologie benignă, evoluția hidatidozei hepatice poate duce la complicații severe şi la scăderea calității vieții pacienților, atât înainte cât şi după operație. O cunoaştere mai bună a patologiei din spatele evoluției locale a bolii poate influența abordul terapeutic.

Correspondence to: Dr. T.D. Potecă,

Surgical Unit, "Colentina" Clinical Hospital, Bucharest, Romania

E-mail: teo_poteca@yahoo.com

\section{REFERENCES}

1. GOTTSTEIN B, REICHEN J, Echinococcosis/hydatidosis. In: Cook GC, ed. Manson's Tropical Diseases, 20 ${ }^{\text {th }}$ ed. London: Saunders; 1996:1486-508

2. BURLUI D, ROSCA M, Chirurgia Chistului Hidatic Hepatic, Editura Medicală , 1977.

3. WEE, Aileen; SAMPATANUKUL, Pichet; JHALA, Nirag. Cytohistology of focal liver lesions. Cambridge University Press, 2014.

4. PEDROSA I, et al. Hydatid Disease: Radiologic and Pathologic Features and Complications 1: (CME available in print version and on RSNA Link). Radiographics, 2000, 20.3: 795-817.

5. De LINDA DF, KAKAR S, Liver Pathology, Demos Medical Publishing, 2011.

6. BELHASSEN-GARCÍA, M et al. Study of hydatidosis-attributed mortality in endemic area. PloS one, 2014, 9.3: 91342.

7. FATOUROU E, et al. Keratin 19 protein expression is an independent predictor of survival in human hepatocellular carcinoma. European Journal of Gastroenterology \& Hepatology, 2015.

8. BATEMAN AC, HÜBSCHER SG. Cytokeratin expression as an aid to diagnosis in medical liver biopsies. Histopathology, 2010, 56.4: 415-425.

9. JAIN R, FISCHER S, SERRA S, CHETTY R, The use of Cytokeratin 19 (CK19) immunohistochemistry in lesions of the pancreas, gastrointestinal tract, and liver, Appl Immunohistochem Mol Morphol. 2010 Jan; 18(1):9-15. doi: 10.1097/PAI. 0b013e3181ad36ea.

10. DERBEL F. et al. Hydatid Cysts of the Liver-Diagnosis, Complications and Treatment. INTECH Open Access Publisher, 2012.

11. TENGURIA RK, NAIK MI. Evaluation of human cystic echinococcosis before and after surgery and chemotherapy by demonstration of antibodies in serum. Annals of parasitology, 2014, 60.4.

12. CANTILlANA MJ, Nuestro criterio diagnóstico y terapéutico en la Hidatidosis Hepática. Rev. Esp. Enf. Ap. Digest. 1996.

13. AMMANN R W, ECKERT J. Cestodes. Echinococcus. Gastroenterol Clin North Am 1996; 25: 655-689. 
14. SINGH D, SHANKAR R, GONDAL R, MALHOTRA V, MISHRA P. Idiopathic eosinophilic cholecystitis with cholelithiasis: A case report and review of literature. The Internet Journal of Surgery. 2007, Volume 16, Number 1.

15. PAN Z, HUNTER W, Hydatid cyst of the liver: A case report and review of the literature. The Internet Journal of Parasitic Diseases. 2006, Volume 2, Number 1.

16. CANDA MP, GRAY M, CANDAT, ASTARCIOÚLU H. The pathology of echinococcosis and the current echinococcosis problem in western Turkey (a report of pathologic features in 80 cases), Turk J Med Sci33 (2003) 369-374.

17. SELEK A, SELEK MB, KARADAYI N, Evaluation of the cystic echinococcosis cases diagnosed in dr. Lütfi Kirdar Kartal education and research hospital pathology laboratory between 2007 and 2013, Turkiye Parazitol Derg. 2015 Jun; 39(2):112-6. doi: $10.5152 /$ tpd.2015.3675.

Received August 20, 2015 